${ }^{\prime}||||||||||$

Rulison Monitoring Plan

July 2010

Approved for public release; further dissemination unlimited

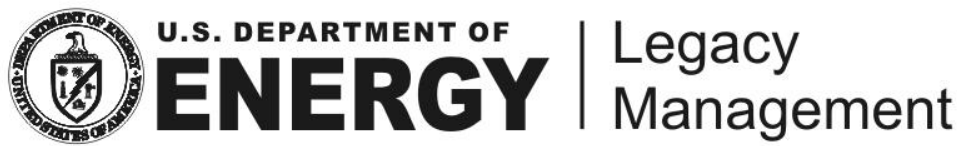


This page intentionally left blank 


\section{Rulison Monitoring Plan}

July 2010

Approved for public release; further dissemination unlimited 
This page intentionally left blank 


\section{Contents}

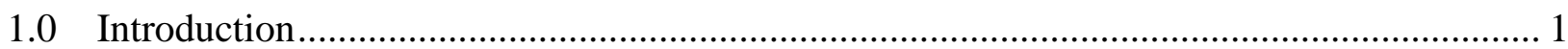

2.0 Radionuclide Source Term and the Potential for Migration.................................................. 1

2.1 Blast Phenomenology and Source Location ................................................................. 1

2.2 Source Term Radionuclides ................................................................................... 3

2.3 Radionuclides Removed by Production Testing........................................................... 4

2.4 Summary of Radionuclide Migration Potential ............................................................. 4

3.0 Transport Pathway and Where to Monitor............................................................................. 5

4.0 What to Sample..................................................................................................... 5

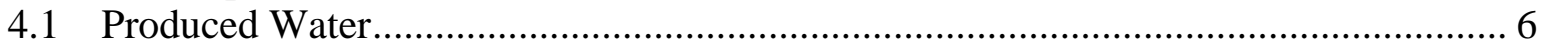

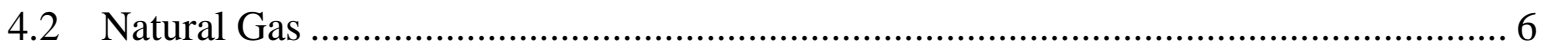

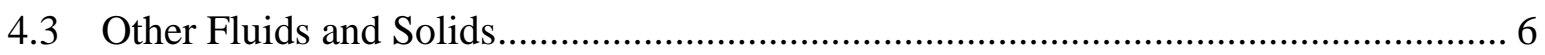

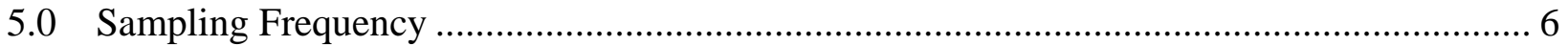

6.0 Sample Analysis: Radionuclides, Action Levels, and Reporting …..................................... 7

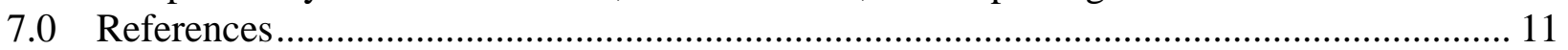

\section{Figure}

Figure 1. Sampling Frequencies Color Coded for Individual Lots Within 1 Mile of Rulison Ground Zero

\section{Tables}

Table 1. Screening and Action Concentrations for Gas and Produced-Water Samples Collected from Gas-Producing Wells............................................................................................. 8

Table 2. Example Response Scenarios ....................................................................................... 9 
This page intentionally left blank

Page ii 


\subsection{Introduction}

The Project Rulison Monitoring Plan has been developed as part of the U.S. Department of Energy (DOE) Office of Legacy Management's mission to protect human health and the environment. The purpose of the plan is to monitor fluids from gas wells for radionuclides that would indicate contamination is migrating from the Rulison detonation zone to producing gas wells, allowing action to be taken before the contamination could pose a risk. The Monitoring Plan (1) lists the contaminants present and identifies those that have the greatest potential to migrate from the detonation zone (radionuclide source term), (2) identifies locations that monitor the most likely transport pathways, (3) identifies which fluids will be sampled (gas and liquid) and why, (4) establishes the frequency of sampling, and (5) specifies the most practical analyses and where the analysis results will be reported. The plan does not affect the long-term hydrologic sampling conducted by DOE since 1972, which will continue for the purpose of sampling shallow groundwater and surface water near the site. The Monitoring Plan was developed in anticipation of gas wells being drilled progressively nearer the Rulison site.

DOE sampled 10 gas wells in 1997 and 2005 at distances ranging from 2.7 to 7.6 miles from the site to establish background concentrations for radionuclides. In a separate effort, gas industry operators and the Colorado Oil and Gas Conservation Commission (COGCC) developed an industry sampling and analysis plan that was implemented in 2007. The industry plan requires the sampling of gas wells within 3 miles of the site, with increased requirements for wells within 1 mile of the site. The DOE plan emphasizes the sampling of wells near the site (Figure 1), specifically those with a bottom-hole location of 1 mile or less from the detonation, depending on the direction relative to the natural fracture trend of the producing formation. Studies indicate that even the most mobile radionuclides created by the test are unlikely to migrate appreciable distances (hundreds of feet) from the detonation zone (Cooper et al. 2007, 2009). The Monitoring Plan was developed to provide a cautious and comprehensive approach for detecting any potential contaminant migration from the Rulison test site. It also provides an independent confirmation of results from the industry sampling and analysis plan while effectively increasing the sampling frequency of wells near the site.

\subsection{Radionuclide Source Term and the Potential for Migration}

\subsection{Blast Phenomenology and Source Location}

The extremely high temperatures associated with a subsurface nuclear detonation vaporize a volume of rock and produce a roughly spherical cavity surrounding the blast point. A highpressure shock wave spreads from the blast, fracturing the rock beyond the cavity wall to a distance related to the yield of the device, depth of burial, and the rock properties. As the high temperatures decrease, the vaporized rock condenses to a liquid melt that flows to the base of the cavity. Within minutes to hours after the detonation the fractured rock above the cavity usually collapses, forming a rubble-filled chimney. The chimney region extends upward from the base of the former cavity to where open fractures end and a stable vaulted ceiling forms. Chimney height correlates closely to the limit of shear failure. The rubble zone with rock fragments entrained in a glassy matrix forms when the cavity collapses into the basal melt zone. The relatively rapid rate of cooling causes the solidified melt rock to have a vitreous texture (melt glass). 


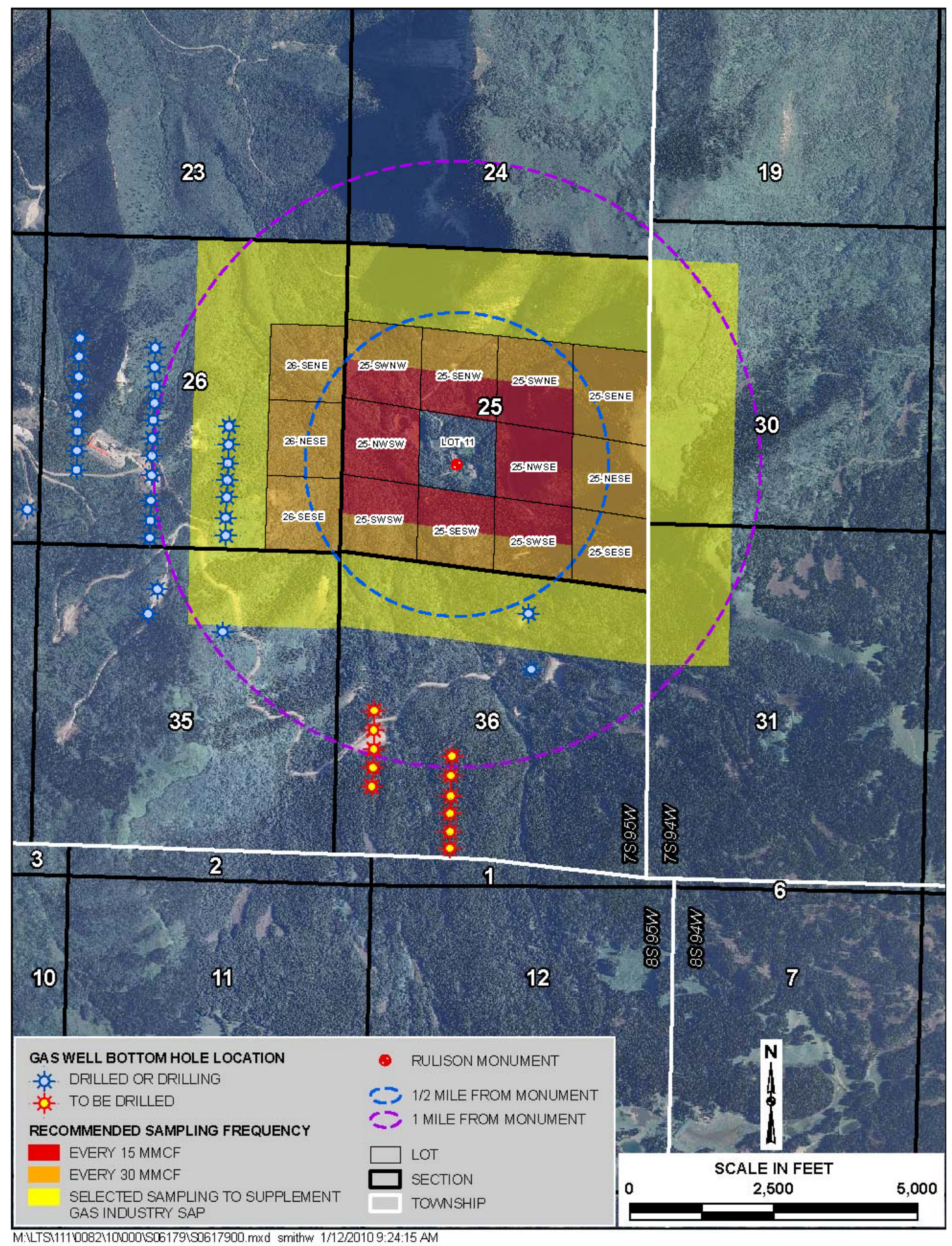

Figure 1. Sampling Frequencies Color Coded for Individual Lots Within 1 Mile of Rulison Ground Zero Section and cardinal quarter-quarter locations are shown for each color-coded lot. 
Examples from the Nevada Test Site can be seen in Kersting and Smith (2006). A more-detailed description of blast phenomenology can be found in Borg et al. (1976) and Pawloski (1999). The detonation zone (chimney and adjacent nuclear fractures) is the source location of the radionuclides that remain after an underground nuclear detonation.

The cavity created by the Rulison test was estimated to have a radius of 76 feet (ft) (72-78 ft). The depth of the top of the Rulison chimney was determined to be the point at which circulation was lost in the post-shot drill-back hole, $275 \mathrm{ft}$ above the detonation point and at a height equal to the limit of shear failure, creating a chimney about $350 \mathrm{ft}$ in height (Reynolds 1971).

\subsection{Source Term Radionuclides}

An underground nuclear detonation produces a number of radionuclide contaminants with the potential to migrate with passing fluids (liquid and gas). The radionuclides include unburned fissile fuel such as uranium (U) and plutonium $(\mathrm{Pu})$ isotopes, fission products such as cesium-137 (Cs-137) and strontium-90 (Sr-90), activation products from neutron bombardment of device hardware and the surrounding geology, and tritium (Bowen et al. 2001). Not all radionuclides produced by a detonation pose a long-term hazard. Radionuclides with short halflives that quickly decay to undetectable levels and those produced in amounts so small that they never exceed regulatory limits can safely be disregarded. Radionuclides with properties that make them essentially immobile in certain geologic environments are also of less concern than those that are more mobile in the subsurface. Each radionuclide exists as a solid, liquid, or gas under various temperature and pressure conditions depending on its chemical properties. For instance, most radionuclides have a high melting point, causing them to solidify with and become entrained in the melt rock as it cools. In water-saturated environments, the melt glass can be subject to dissolution, which could potentially lead to the slow release of radionuclides into passing groundwater. Many radionuclides strongly sorb to mineral grains, causing their migration rate to be much slower than the rate of groundwater movement. The migration of radionuclides from melt rock dissolution has been shown to be limited in saturated environments, and in unsaturated environments where formation water is practically immobile (as at the Rulison site), dissolved radionuclides are not expected to move beyond the detonation zone. For all practical purposes, radionuclide isotopes of uranium, plutonium, cesium, and strontium are immobile in the geologic environment surrounding the Rulison detonation zone and are protected from direct access by the existing institutional control area.

Radionuclides that can exist in the gas phase and were created in significant amounts by the Rulison detonation are of primary concern because of their potential mobility. The relative permeability of the gas phase is orders of magnitude greater than that of liquids in the naturalgas-producing reservoirs of the Williams Fork Formation. The gas phase largely consists of methane with smaller amounts of ethane, propane, carbon dioxide, water vapor, and other minor constituents. Gas-phase radionuclides produced by the Rulison detonation (Reynolds 1971) in order of estimated abundance were: approximately 10,000 curies of tritium (an isotope of hydrogen with two neutrons, H-3), approximately 1,100 curies of krypton-85 (Kr-85, a noble gas), and minor amounts of argon isotopes and carbon-14 (C-14). Of these, only tritium was expected to remain in an amount large enough to pose a potential contamination problem, because the other radionuclides were largely removed by production testing (described below) and/or radioactive decay. 


\subsection{Radionuclides Removed by Production Testing}

A reentry well was drilled into the Rulison chimney and tested to determine the success of the detonation at improving gas production. The well produced 455 million cubic feet (MMCF) of gas in 107 days of testing that took place from October 1970 through April 1971. The produced gas was flared to the atmosphere, and samples of the produced gas and produced water (much of which was condensed water vapor) were collected and analyzed to determine the degree to which radioactivity levels changed as testing progressed. All releases during drilling and testing were monitored by the U.S. Environmental Protection Agency (EPA) National Environmental Respiratory Center and the Colorado Department of Public Health to protect workers at the site, the public, and the environment (AEC 1973).

As expected, the radioactivity levels decreased throughout the testing as gas from the chimney region was produced, burned, and replenished by unaffected gas from the surrounding formation. Sample analysis indicated that approximately 1060 of the 1100 curies of Kr-85 were removed by the production testing (Smith 1971). The concentration of Kr-85 in the produced gas (well-mixed throughout the detonation zone due to its inert nature) was closely monitored throughout the testing to determine when radioactive gas from the detonation zone was depleted. After radioactive decay, less than 7 percent of any Kr-85 that was not removed by testing would remain in 2009. Sample results also indicate that the estimated 2.5 curies of C-14 produced by the detonation was removed during the production testing.

Approximately 3000 of the original 10,000 curies of tritium were removed by the production testing, leaving 7000 curies of tritium that would have decayed to 700 curies by 2009. Tritium was initially present in hydrocarbons (mostly methane with lesser amounts of ethane and propane), hydrogen gas, and water (vapor and liquid). Production testing data indicate that essentially all gas-phase tritium was removed from the detonation zone. The remaining tritium is likely present in liquid water and in minerals that make up the melt rock.

Tritium does not exchange with normal hydrogen atoms in hydrocarbons except at the very high temperatures that occur during and soon after the detonation. If most of the remaining tritium is in the melt rock, there is no significant source of mobile radionuclides at Rulison. However, if it is mostly present in liquid water, it could be a long-term tritium source (until it decays) that can evaporate to form tritiated water vapor.

\subsection{Summary of Radionuclide Migration Potential}

The only mobile radionuclide that remains in the Rulison detonation zone in a quantity sufficient to be of concern is tritium, which can be present in both the gas (high mobility) and liquid (low mobility) phases. The other gas-phase radionuclides (C-14, Kr-85, and argon isotopes) present after the detonation tend to exist primarily in the gas phase and were removed from the detonation zone by the production testing. For these reasons, DOE sampling will primarily focus on the detection of tritium. Produced water samples from gas wells will also be analyzed for radioactivity expressed in gross alpha (Pu or U), gross beta (Cs-137 or Sr-90), and highresolution gamma (most alpha and beta decays have associated gamma emissions) to confirm that no migration of water from the detonation zone occurs. 


\subsection{Transport Pathway and Where to Monitor}

The most likely transport mechanism to the surface for tritiated water vapor in or near the Rulison detonation zone is with natural gas extracted from a nearby production well. To be of concern, the well would have to be close enough to interact with the potentially contaminated region. Wells in this part of the Piceance Basin typically drain an area of roughly $1200 \mathrm{ft}$ by $300 \mathrm{ft}$ (10 acres), with the long axis oriented east-west, along the natural fracture trend in the Williams Fork Formation. In practice, this requires four wells per quarter-quarter section (centered east-west and aligned north-south) to drain each 40 acre parcel. The majority of wells installed at this spacing do not interact with one another or with wells in adjacent 40-acre lots. It is evident that wells east and west of the detonation zone would be in the most susceptible transport direction due to the increased permeability in that direction. If production history holds for wells near the Rulison site, natural gas within Lot 11 (the institutional control area) should not be captured by wells located in adjacent lots, including those to the east and west.

Shortly after the detonation, gas-phase contaminants were spread through the nuclear chimney and likely through the adjacent nuclear-fractured region. Reentry well production testing in the second year removed about two chimney volumes of gas and created an inward pressure gradient that persisted for years, drawing contaminants from the nuclear-fractured region back to the chimney (and out the wellbore during testing). Analysis of the pressure data collected at the reentry well indicated that the nuclear fracturing increased permeability out to about $209 \mathrm{ft}$ from the detonation, assuming a spherical fractured region (Rubin et al. 1972). It is expected that as the effects of the testing dissipated, gaseous diffusion has likely caused tritium to spread back throughout the region of increased permeability and possibly beyond.

The preceding information, along with the results of the transport modeling (Cooper et al. 2007, 2009), strongly suggests that monitoring of gas and liquids produced by wells in lots adjacent to Lot 11 is sufficient to detect any potential contaminant migration from the Rulison detonation. However, to be cautious with the initial development of gas reserves near Rulison, DOE plans to monitor production from gas wells as far as 1 mile east and west of the detonation zone (higher permeability direction) and as far as one-half mile north and south of the detonation (Figure 1). As stated in the draft Rulison Path Forward document (DOE 2009), monitoring of wells at the farthest distances adds a safety factor to the calculated safe distance and allows the absence of contamination to be confirmed before wells are drilled nearer the site. As wells are drilled nearer the site, wells that are effectively separated (based on expected drainage patterns) from the site by a well or wells closer to the detonation zone will be phased out of routine monitoring.

\subsection{What to Sample}

Gas wells in the Piceance Basin produce some liquids (produced water and minor amounts of hydrocarbons) along with natural gas. The transport mechanism, tritiated water vapor migrating with natural gas, allows detection of tritium in either the gas or liquid phases. Analyses of water vapor separated from gas and of produced water (a significant fraction is from water vapor that condenses at surface temperature and pressures) should give similar results. Additionally, the exchange of water between migrating water vapor and liquid formation water occurs quickly enough that tritium concentrations should approach equilibrium between the two phases. 


\subsection{Produced Water}

The DOE Monitoring Plan focuses on produced water as the key medium to sample. Industry natural gas standards for the Rulison area require that the natural gas be 95 percent dry at the time it leaves the wellhead. Liquid water, water vapor, and hydrocarbon condensate brought to the surface with the natural gas stream are mechanically separated (dried) at the wellhead. The produced water samples will be analyzed for tritium and for gross alpha, gross beta, and gamma emitters (by high-resolution gamma spectrometry). Table 1 shows the laboratory analytical methods and detection limits.

\subsection{Natural Gas}

The primary components of natural gas that can contain tritium are methane and water vapor. The tritium present as tritiated methane was believed to be depleted as concentrations decreased throughout the reentry well testing, which removed and flared two chimney volumes of gas from the detonation zone. Tritium present as tritiated water vapor can effectively be monitored by analyzing produced water samples. Natural gas will be sampled and analyzed to confirm that no tritiated methane, if present, is migrating from the detonation zone. Table 1 shows the laboratory analytical methods and detection limits. Natural gas samples will be collected at well locations and at a frequency dictated by the Monitoring Plan (see Figure 1).

\subsection{Other Fluids and Solids}

Drill cuttings, along with drilling, hydrofracturing, and flowback fluids are being sampled and analyzed under the industry Sampling and Analysis Plan. DOE recognizes the importance of this sampling to document the presence or lack of contaminants at a newly drilled location and to document that fluids introduced by drilling and completion processes do not introduce radionuclides that could give a false indication of test-related contaminants. However, DOE does not currently plan to replicate the industry sampling during well installation.

\subsection{Sampling Frequency}

Sampling frequency is determined by considering (1) the distance between the gas well producing interval and the institutional control area (Lot 11), (2) the expected orientation of the well's drainage area given the natural fracture trend, and (3) the fraction of gas produced relative to the expected lifetime production of the well.

It is logical that wells with bottom-hole locations nearer the detonation zone should be sampled more frequently. Wells at similar distances that are in line with the natural fracture trend from the detonation zone should also be sampled more frequently due to the higher permeability in this direction and the elongated drainage pattern that results from hydrofractures extending farther in this direction. These factors call for the sampling of wells in an elongated sampling area shown in Figure 1.

Individual wells in the Piceance Basin are estimated to produce between 1 and 1.5 billion cubic feet (BCF) of gas over the life of the well. Production rates are initially high at 15 to $20 \mathrm{MMCF}$ per month and then decline over time to a few MMCF per month. A sampling frequency based on percentage of gas produced relative to the total expected to be produced over the life of the well results in samples being collected more frequently when a well is initially brought on line 
and less frequently later. This provides more sampling during the period when the area of influence of the well is expanding rapidly and less sampling when the extent of the area of influence has stabilized. The initial production is not only from the zone near the well but also from the more permeable hydrofractures that propagated relatively far from the well along the more permeable preexisting fractures of the natural fracture trend. Production in the latter stages is dominated by gas migrating relatively short distances from the rock matrix to the fractures. Based on this conceptual model of gas flow to a well, DOE is adopting a sampling frequency tied to volumetric gas production. The frequencies recommended (15 MMCF and $30 \mathrm{MMCF}$ ) are equivalent to sampling every 1 to 3 percent of total production, more frequently for moreproductive wells located close to the detonation zone and less frequently for less-productive wells farther away. For example, sampling every 15 MMCF for a well that will eventually produce $1.5 \mathrm{BCF}$ is the equivalent of sampling every 1 percent of total production. However, if the well eventually produces only 1.0 BCF, it is the equivalent of sampling every 1.5 percent of total production. The percentages are doubled for sampling at $30 \mathrm{MMCF}$.

The recommended sampling frequency for wells in the vicinity of the Rulison site is illustrated by the color coding of lots presented on Figure 1. Wells in the "sampling shadow" of wells nearer the detonation zone will be considered for reduced sampling frequency and eventual removal from routine monitoring. The recommended sampling frequencies constitute guidelines to coordinate sampling; actual sampling may be conducted more or less frequently depending on weather conditions, number of wells to be sampled, and results of efforts to coordinate with industry sampling.

\subsection{Sample Analysis: Radionuclides, Action Levels, and Reporting}

All samples will be analyzed for tritium. Produced water will also be analyzed for gross alpha, gross beta, and high-resolution gamma activity to monitor for the unlikely event that less-mobile radionuclides such as isotopes of $\mathrm{Pu}, \mathrm{U}$, or $\mathrm{Cs}$ have migrated from the detonation zone. Screening and action levels for gas and produced water sample results are presented in Table 1. The action levels will be risk based and are listed as "to be determined" (TBD) until appropriate levels are determined.

If the screening level (but not the action level) is exceeded (by a gas or produced water sample result), the analytical laboratory will be directed to reanalyze the sample (if possible), and another sample will be collected and sent to the lab for analysis. If the result is not validated by the additional results, there will be no change in sampling. If the result is validated and is for tritium with no indication of other radionuclides, real-time monitoring for tritium will be installed at this well. If the result is validated and is indicative of alpha or beta decay, the laboratory will analyze the sample to determine the specific radionuclide. Sampling frequency will be increased, and all data pertaining to the well and any nearby wells will be reviewed.

A risk analysis is in progress to set action levels based on risk. If an action level is exceeded by a validated result, samples will be collected for further analysis, and the well in question will be shut in until the situation can be assessed. Nearby wells will be sampled, and their sampling frequency will be increased.

All monitoring results will be reported on the DOE Office of Legacy Management website, and any validated results that exceed screening levels will be reported to the well operator and state agencies (Table 2). 
Table 1. Screening and Action Concentrations for Gas and Produced-Water Samples Collected from Gas-Producing Wells.

\begin{tabular}{|c|c|c|c|c|c|c|c|}
\hline \multicolumn{8}{|c|}{ Methane Gas Samples } \\
\hline Radionuclide & Laboratory & $\begin{array}{l}\text { Analytical } \\
\text { Method }\end{array}$ & $\begin{array}{l}\text { Reporting } \\
\text { Units }\end{array}$ & \begin{tabular}{|c|} 
Requested \\
Detection Limit
\end{tabular} & $\begin{array}{c}\text { Screening } \\
\text { Concentration }\end{array}$ & $\begin{array}{c}\text { Action } \\
\text { Concentration }\end{array}$ & Comment \\
\hline Tritium & Isotech & Lab specific & $\begin{array}{c}\text { TU } \\
\text { (Tritium Unit) }\end{array}$ & $10 \mathrm{TU}$ & $\begin{array}{l}19,293 \mathrm{TU} \\
(0.10 \mathrm{pCi} / \mathrm{cc})\end{array}$ & TBD & \\
\hline \multicolumn{8}{|c|}{ Produced Water Samples (Note 3) } \\
\hline \multirow[t]{2}{*}{ Tritium } & ALS Paragon & EPA 906.0 & $\begin{array}{c}\mathrm{pCi} / \mathrm{L} \\
\text { (picocuries per } \\
\text { liter) }\end{array}$ & 400 & $800 \mathrm{pCi} / \mathrm{L}$ & TBD & $\begin{array}{l}\text { The drinking water standard is } \\
20,000 \mathrm{pCi} / \mathrm{L} \text {. }\end{array}$ \\
\hline & GEL & EPA 906.0 & $\mathrm{pCi} / \mathrm{L}$ & 400 & $800 \mathrm{pCi} / \mathrm{L}$ & TBD & \\
\hline \multicolumn{8}{|c|}{ Method } \\
\hline \multirow{2}{*}{$\begin{array}{l}\text { H-R Gamma } \\
\text { Spectrometry }\end{array}$} & ALS Paragon & EPA 901.1 & $\mathrm{pCi} / \mathrm{L}$ & 10 & $20 \mathrm{pCi} / \mathrm{L}$ & TBD & $\begin{array}{l}\text { Requirements for Cesium-137 } \\
\text { are shown. }\end{array}$ \\
\hline & GEL & EPA 901.1 & $\mathrm{pCi} / \mathrm{L}$ & 10 & $20 \mathrm{pCi} / \mathrm{L}$ & TBD & \\
\hline \multirow[t]{2}{*}{ Gross Alpha } & ALS Paragon & $\begin{array}{l}\text { EPA } 900.0 / \\
\quad 9310\end{array}$ & $\mathrm{pCi} / \mathrm{L}$ & 2 & $3 x$ background & TBD & $\begin{array}{l}\text { Method sensitive to total } \\
\text { dissolved solids in the } \\
\text { sample. }\end{array}$ \\
\hline & GEL & $\begin{array}{l}\text { EPA } 900.0 / \\
9310\end{array}$ & $\mathrm{pCi} / \mathrm{L}$ & 2 & $3 x$ background & TBD & \\
\hline \multirow{2}{*}{ Gross Beta } & ALS Paragon & $\begin{array}{l}\text { EPA } 900.0 / \\
\quad 9310\end{array}$ & $\mathrm{pCi} / \mathrm{L}$ & 4 & $3 x$ background & TBD & $\begin{array}{l}\text { Method sensitive to total } \\
\text { dissolved solids in the } \\
\text { sample. }\end{array}$ \\
\hline & GEL & $\begin{array}{l}\text { EPA } 900.0 / \\
9310\end{array}$ & $\mathrm{pCi} / \mathrm{L}$ & 4 & $3 \times$ background & TBD & \\
\hline
\end{tabular}

Notes:

1 The derived air effluent concentration for a 50 millirem/year dose from tritium exposure is $1 \times 10^{-7}$ microcuries per cubic centimeter or 0.10 picocuries per cubic centimeter $(\mathrm{pCi} / \mathrm{cc})$. The units picocuries of tritium per cubic centimeter of methane are selected to make the distinction between the liquid water and dry methane gas $\left(\mathrm{CH}_{4}\right)$ phases. Useful conversions are: $5.183 \times 10^{-6} \mathrm{pCi} / \mathrm{cc} /(\mathrm{TU})$; and $2.832 \times 10^{4} \mathrm{cc} / \mathrm{ft}^{3}$.

2 Tritium screening concentrations are selected to be 2 times the nominal laboratory minimum detectable concentration. The detection limit listed is for drinking water.

3 Total dissolved solids in the sample have a significant effect on the minimum detectable concentration achievable. 


\begin{tabular}{|c|c|c|c|c|}
\hline Radionuclide & $\begin{array}{c}\text { Screening } \\
\text { Concentration }\end{array}$ & $\begin{array}{c}\text { Screening Concentration < Sample Analysis Result < Action } \\
\text { Concentration }\end{array}$ & $\begin{array}{c}\text { Action } \\
\text { Concentration }\end{array}$ & Sample Analysis Result > Action Concentration \\
\hline Tritium & $\begin{array}{l}19,300 \mathrm{TU} \\
(0.10 \mathrm{pCi} / \mathrm{cc})\end{array}$ & $\begin{array}{l}\text { 1. Collect a new sample of natural gas. Repeat the analyses to validate the } \\
\text { original result. If the original result is not validated, continue the sample } \\
\text { collection frequency; if the original result is validated proceed to step } 2 \text {. } \\
\text { 2. Notify the DOE site lead. } \\
\text { 3. Increase the annual sampling frequency to the next larger frequency (in the } \\
\text { DOE Monitoring Plan) or every } 2 \text { months, whichever is smaller. } \\
\text { 4. Collect a natural gas sample from the gas line input at the nearest } \\
\text { downstream compressor station. If the result is greater than the screening } \\
\text { concentration, notify the DOE site lead and collect another sample for } \\
\text { verification analysis. }\end{array}$ & $\begin{array}{c}38,600 \mathrm{TU} \\
(0.20 \mathrm{pCi} / \mathrm{cc})\end{array}$ & $\begin{array}{l}\text { 1. Collect a new sample of natural gas. Repeat the analysis to validate the original tritium result. If the original } \\
\text { tritium result is not validated, continue the sample collection frequency; if the original result is validated proceed } \\
\text { to step } 2 \text {. } \\
\text { 2. Notify the DOE site lead. DOE notifies the State. } \\
\text { 3. Increase the annual sampling frequency to the next larger frequency (in the DOE Monitoring Plan) or every } \\
\text { month, whichever is smaller. } \\
\text { 4. Collect two new gas samples for tritium analysis: (1) from the gas line input at the nearest downstream } \\
\text { compressor station and (2) at the output of the treatment plant (before the pipeline). If either result exceeds the } \\
\text { action concentration, notify DOE and proceed to step } 5 \text {. } \\
\text { 5. Shut in half the wells with tritiated methane that exceed the action concentration; repeat step } 4 \text {. }\end{array}$ \\
\hline Carbon-14 & $\begin{array}{c}2 \mathrm{pMC} \\
\left(6.54 \times 10^{-5}\right. \\
\mathrm{pCi} / \mathrm{cc})\end{array}$ & See above & $\begin{array}{c}5 \mathrm{pMC} \\
\left(16.4 \times 10^{-5} \mathrm{pCi} / \mathrm{cc}\right) \\
\end{array}$ & See above \\
\hline
\end{tabular}

\section{Produced Water}

\begin{tabular}{|c|c|c|c|c|}
\hline Radionuclide & $\begin{array}{l}\text { Screening } \\
\text { Concentration }\end{array}$ & $\begin{array}{c}\text { Screening Concentration < Sample Analysis Result }<\text { Action } \\
\text { Concentration }\end{array}$ & $\begin{array}{c}\text { Action } \\
\text { Concentration }\end{array}$ & Sample Analysis Result > Action Concentration \\
\hline Tritium & $400 \mathrm{pCi} / \mathrm{L}$ & $\begin{array}{l}\text { 1. Direct the analytical laboratory to reanalyze the original produced water } \\
\text { sample or collect a new sample of produced water to validate the original } \\
\text { tritium result. If the original tritium result is not validated, continue the sample } \\
\text { collection frequency; if the original result is validated, proceed to step } 2 \text {. } \\
\text { 2. Notify the DOE site lead. } \\
\text { 3. Review the well construction, geophysical logs, and fracture water } \\
\text { radionuclide composition with the well operator. } \\
\text { 4. Increase the annual sampling frequency to the next larger frequency (in the } \\
\text { DOE Monitoring Plan) or every } 2 \text { months, whichever is smaller. } \\
\text { If validated tritium results from three consecutive samples of produced water } \\
\text { (according to the DOE Monitoring Plan) are above the screening concentration, } \\
\text { and if a new gas well is planned within the zone defined by the sampled-well } \\
\text { 10-acre hydrofracture zone and ground zero, establish a protocol with COGCC } \\
\text { and the operator for geophysical measurements to be made before, during, and } \\
\text { after hydrofracture of the new gas well. }\end{array}$ & $15,000 \mathrm{pCi} / \mathrm{L}$ & 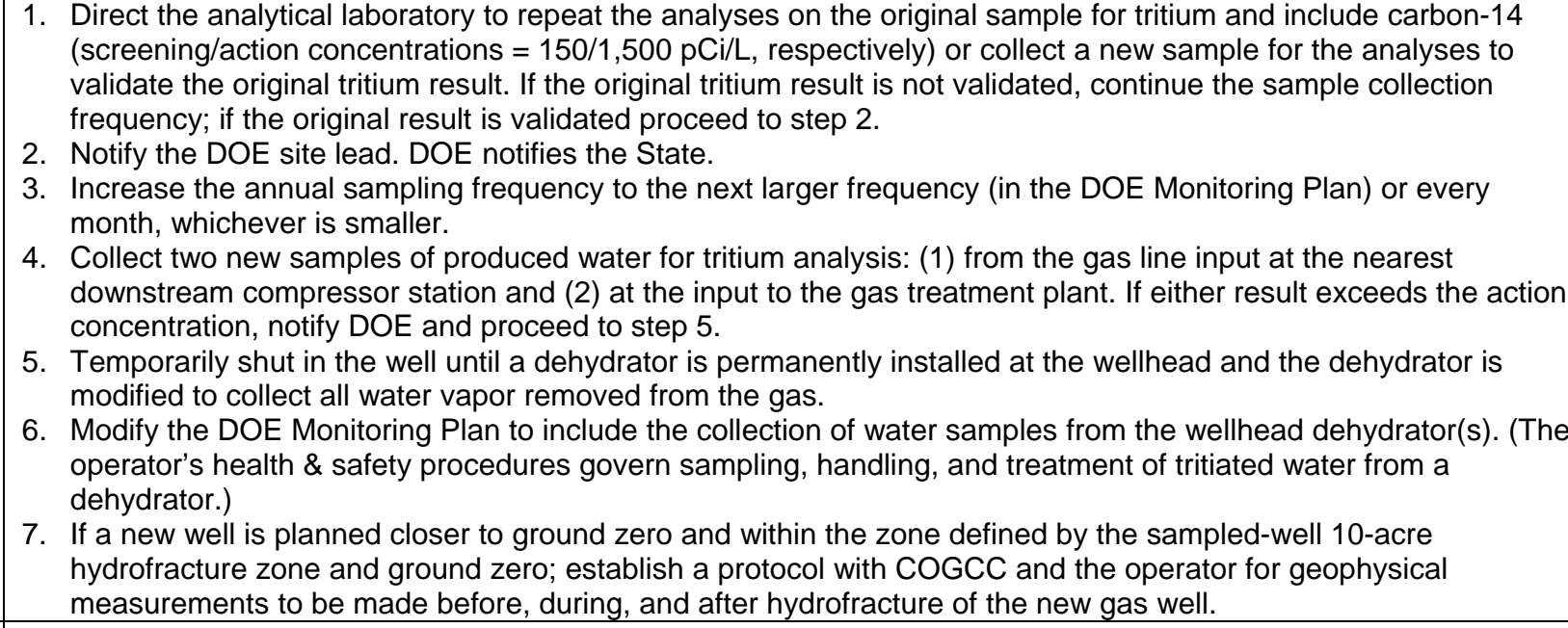 \\
\hline $\begin{array}{l}\text { High-Resolution } \\
\text { Gamma } \\
\text { Spectrometry }\end{array}$ & $\begin{array}{c}15 \mathrm{pCi} / \mathrm{L} \\
\text { (for cesium-137) }\end{array}$ & $\begin{array}{l}\text { 1. Direct the analytical laboratory to reanalyze the original water sample and } \\
\text { include strontium-90 or collect a new water sample for the analyses to } \\
\text { validate the original gamma-spectrometry result. If the original result is not } \\
\text { validated, continue the sample collection frequency; if the original result is } \\
\text { validated proceed to step } 2 \text {. } \\
\text { 2. Notify the DOE site lead. } \\
\text { 3. Increase the annual sampling frequency to the next larger frequency (in the } \\
\text { DOE Monitoring Plan) or every } 2 \text { months, whichever is smaller. } \\
\text { 4. If the cesium-137 validated concentration exceeds the screening } \\
\text { concentration, add strontium-90 to the produced water analytes in the DOE } \\
\text { Monitoring Plan (screening/action concentrations }=3 / 6 \text { pCi/L, respectively). }\end{array}$ & $\begin{array}{c}150 \mathrm{pCi} / \mathrm{L} \\
\text { (for cesium-137) }\end{array}$ & $\begin{array}{l}\text { 1. Direct the analytical laboratory to reanalyze the original water sample and include strontium-90 or collect a new } \\
\text { sample of produced water for the analyses to validate the gamma spectrometry result. If the original result is not } \\
\text { validated, continue the sample collection frequency; if the original result is validated, proceed to step } 2 \text {. } \\
\text { 2. Notify the DOE site lead. } \\
\text { 3. Increase the annual sampling frequency to the next larger frequency (in the DOE Monitoring Plan) or every } \\
\text { month, whichever is smaller. } \\
\text { 4. Consider shutting in the well. }\end{array}$ \\
\hline Gross Beta & $\begin{array}{c}3 \text { times } \\
\text { background }\end{array}$ & Monitor trend & & \\
\hline Gross Alpha & $\begin{array}{c}3 \text { times } \\
\text { background }\end{array}$ & Monitor trend & & \\
\hline
\end{tabular}




\section{Assumptions:}

- Gas samples are collected between the separator and the wellhead or after and near the wellhead separator.

- Produced water samples are collected before the storage tank.

- The screening and action levels for the analytes DOE monitors are adopted from the operator's Sampling and Analysis Plan (March 2008, Version 2). Differences are noted in Table B-2, DOE Monitoring Plan.

- If the derived concentration for a gamma-emitting radionuclide is not defined, use the average laboratory detection limit.

- A sample result between the screening and action level and a result greater than the action level are considered independently.

The screening and action levels for methane are for dried and filtered gas at standard temperature and pressure.

- Every result above a screening or action concentration requires resample and analyses (gas) or reanalysis of the original sample (water) for verification; if the result is verified, notify DOE.

The "next higher frequency" is given in Table B-1, DOE Monitoring Plan.

- The bottom-hole location is intended in all direct or implied references to well location 


\subsection{References}

AEC (U.S. Atomic Energy Commission), 1973. Project Rulison: Managers Report, NVO-71, PNE-R-63, Nevada Operations Office, Las Vegas, Nevada.

Borg, I.Y., R. Stone, H.B. Levy, and L.D. Ramspott, 1976. Information Pertinent to the Migration of Radionuclides in Ground Water at the Nevada Test Site, Part 1: Review and Analysis of Existing Information. Lawrence Livermore National Laboratory report UCRL522078 Pt. 1, 216p.

Bowen, S.M., D.L. Finnegan, J.L. Thompson, C.M. Miller, P.L. Baca, L.F. Olivas, C.G. Geoffrion, D.K. Smith, W.Goishi, B.K.Esser, J.W. Meadows, N. Namboodiri, and J.F. Wild, 2001. Nevada Test Site Radionuclide Inventory, 1951-1992, LA-13859-MS, Los Alamos National Laboratory, September.

Cooper, C.A., Ming Ye, and J.B. Chapman, 2007. Tritium Transport at the Rulison Site, a Nuclear-Stimulated Low-Permeability Natural Gas Reservoir, Desert Research Institute Report No. 45224, same as U.S. Department of Energy (DOE) Office of Legacy Management document DOE/NV/13609-54, DOE M/1522.

Cooper, C.A., Ming Ye, J.B. Chapman, and R.A. Hodges, 2009. Addendum: Tritium Transport at the Rulison Site, a Nuclear-stimulated Low-permeability Natural Gas Reservoir, Desert Research Institute Report.

EPA (U.S. Environmental Protection Agency), 2002. Radionuclides in Drinking Water: A Small Entity Compliance Guide, EPA-815-R-02-001, February

DOE (U.S. Department of Energy), 2009. Rulison Path Forward, LMS/RUL/S04617, Office of Legacy Management, Grand Junction, CO, June.

Kersting, A.B. and D.K. Smith, 2006. Observations of Nuclear Melt Glass Textures and Surface Areas, Lawrence Livermore National Laboratory, UCRL-TR-218361, January 24.

Pawloski, G., 1999. Development of Phenomenological Models of Underground Nuclear Tests on Pahute Mesa, Nevada Test Site-BENHAM and TYBO, UCRL-ID-136003, Lawrence Livermore National Laboratory.

Reynolds, M., 1971. Project Rulison-Summary of Results and Analyses, presented at the American Nuclear Society winter meeting, Miami, FL.

Rubin, B., L. Schwartz, and D. Montan, 1972. An Analysis of Gas Stimulation Using Nuclear Devices, UCRL-51226, Lawrence Livermore Laboratory, May 15.

Smith, C.F., 1971. Gas Analysis Results for Project Rulison Production Testing Samples, UCRL-ID-51153, Lawrence Livermore National Laboratory. 
This page intentionally left blank

Page 12 